\title{
Pathological study of the toxic effect of paracetamol on reproductive organs in white mice
}

\author{
A. G. Rhayf \\ S. K. Majeed \\ Coll. of Vet. Med./ Univ of AL-Qadisya Coll. of Vet. Med./ Univ AL-Basrah
}

\section{Abstract}

In present study use 40 mice (20 male and 20 females) divided into 4 groups, each group has 10 mice.The first group gave distal water considered as control group. The second (low dose group) gave $28.5 \mathrm{mg} / \mathrm{kg} \mathrm{B}$.W. paracetamol. The third group(intermediate dose group) gave $57 \mathrm{mg} / \mathrm{kg} \mathrm{B}$.W. paracetamol and fourth group(high dose group) gave $114 \mathrm{mg} / \mathrm{kg} \mathrm{B.W}$. paracetamol daily for 6 month. Also there was another group considerd as peracute dose group(supra toxic) contains from 2 males and 2 females gave $342 \mathrm{mg} / \mathrm{kg} \mathrm{B}$.W. (for 2 weeks).The toxic and supra toxic dose of paracetamol caused macroscopic and microscopic changes in male and female reproductive organs in white mice.

\section{Introduction}

The popular domestic analgesic and anti pyretic for adult and children is paracetamol, it is a major metabolite of new obsolete phenacetin, it's analgesic efficacy is equal to that of aspirin but in therapeutic dose it has only weak antiinflammatory effect (1).Paracetamol is a highly popular antipyretic in the 1950s and now the antipyretic of the first choice in most develop countries, due to the disadvantages of administration of NSAIDs, which is gastro toxicity manifested as irritation, ulcer and bleeding of gastric mucosa so paracetamol the drug of choice for reducing pain in the future (2). It is effective in mild to moderate pain such as headache, fever and dysmenorrheal (3).The painkilling properties of paracetamol discovered accidentally when a similar molecule (acetanilide) added to a patients prescription approximately 100 years ago.Paracetamol was first use in medicine by Von mering in 1983; however, it has gained popularing only since 1949, after it recognized as the major active metabolite of both acetanilide and phenacetin (4).It's potent analgesic and antipyretic drug but it has only weak antiinflammatory activity, unlike aspirin-like drug (5). The failure of paracetamol to exert anti-inflammatory activity may be attributed to the fact that paracetamol is only a weak inhibitor of cyclooxygenase in presence of the high concentration of peroxides that are found in inflammatory lesion, also paracetamol does not inhibit neutrophil activation as do other nonsteroidal anti-inflammatory drugs (6).Cyclooxygenase (COX) prostaglandin and peroxide synthetase (PTGs) Catalases the formation of Prostaglandins from arachidonic acid (7).Prostaglandins are lipid signaling mediators that play a central role in broad range of activities including inflammation, reproduction, no-ciception and gastro intestinal protection (7). Paracetamol indirectly block COX and that this blockage ineffective in presence of peroxidase, this explain why paracetamol is effective in the nervous system and endothelial cells but not in platelets and immune cells which have high level of peroxidase(8).(5)reported data suggesting that paracetamol selectively block a variant of cyclooxygenase (COX) enzyme that is different from that Known variant COX-1 and COX-2.The aim: The present study was done to investigate about the risk of overdose of paracetamol in experimental animals in order to find any toxopathological changes specially are those which we are not aware of, also any hidden effect of this compound on reproductive organ in white mice. 
Materials and Methods

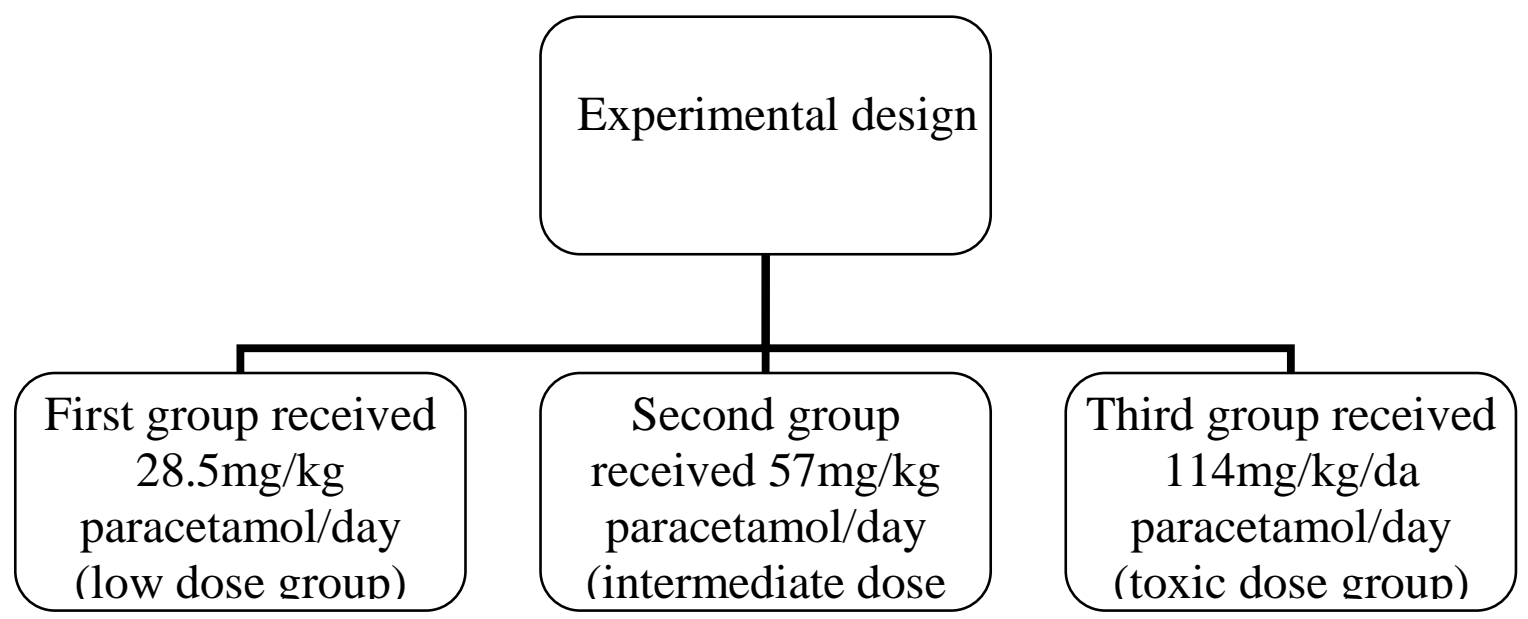

Forty mice (20 males and 20 females) about 1-1.5 months old were divided into 4 equal groups (5 mice of each sex pergroup). Animals of the first three groups received: 28.5, 57 and $114 \mathrm{mg} / \mathrm{Kg}$ paracetamol / day orally for 180 day as low intermediate and high dose respectively, while the control group given distil water.The animals were housed in $6 \times 4 \times$ $3 \mathrm{~m}^{3}$ room under 12 hours light / 12 hours dark at $21 \pm 4 \mathrm{C}^{\mathrm{o}}$ animal housed as 5 mice in each standard plastic cage. Also there was other group (peracute group) consist of ( 2 males and 2 females) dose at $342 \mathrm{~g} /$ $\mathrm{Kg}$ for 2 week.The paracetamol tablet was diluted with distil water that every $10 \mathrm{cc}$

\section{Macroscopic Findings}

There are no significant macroscopic findings in Low Dose Group \& Intermediate Dose Group while in Toxic Dose and Per acute Dose there are obvious macroscopic changes include The testis appear smaller than those in previous groups(low and intermediate group) also the ovaries in female reproductive organs appear small in size and have few ova or absence.

\section{Microscopic Findings}

\section{Control Group:}

There were no significant microscopic signs in control untreated animals.

Group A (Low Dose)and group B (Intermediate Dose):

Also there were no significant microscopic signs in male and female reproductive organs. from solution have $114 \mathrm{mg}$ from paracetamol and then given $0.25 \mathrm{cc}$ of these solution to each mouse and this high dose.So the mixture diluted into $1 / 2$ as intermediate dose and diluted in 1/4 as low dose.At the end of administration time which was six month mice were scarified by ether inhalation.For histopathology, pieces of 1-2 cm3 were taken from reproductive organs and fixed in $10 \%$ formalin, processed routinely and making paraffin block and sections were cut at 5 $\mathrm{Mm}$ thickness by rotary microtom and stained with routine haematoxyline and eosin stain examined under light microscope (9).

\section{Results}

\section{Toxic Dose (High Dose)}

The testes showed inhibition of spermatogenesis and presence of multinucleated giant cells there were occasional (Fig. 1 and 2 ) the epidiedymus was empty with no sperms in lumen (Fig. 3).Ovary appeared with no corpus leutium only few follicles and occasional graffian follicle (Fig. 4).

\section{Peracute Group:}

The Testes: There are testicular changes as spermatid degeneration with development of multinucleated spermatid, giant cells and occasional vaculated spermatogenia (Fig. 5).The ovaries showed loss of corpus leutium, a few follicles and some graffian follicles were present (Fig. 6). 


\section{Discussion}

Paracetamol has been used safely and effectively for many years to manage pain and fever in patient of all ages, it is a non prescription drug be purchased in drugs and supermarket without physician's involvement, Death or severe injury is far more likely occure with its use than with all of other medication (10);(11).For this reason and others, this study had focused on non target organ like reproductive organs. The microscopic changes, which occurred in present study, showed inhibition of spermatogenesis, there are occasional vacuolated spermatogenia with development of multi nucleated spermatid giant cells ; also, the epididymus was empty with no spermatozoa in lumen. These changes probably occurred due to the toxic dose effect of paracetamol cause inhibition of DNA synthesis in testes. These results similar to result of (12);(4) they recorded that daily administration of paracetamol in toxic dose cause reduction in relative testicular weight in mice due to inhibit DNA synthesis in testis, there was neither a depletion of glutathione or a marked increase in covalent binding. While empty of epididmis indicating that there was no production of sperms in the testes. While development of multi nucleated spermatid giant cells is due to inflammatory response due to paracetamol toxicity. The ovary showed no corpus Leutea only few follicles and some graffian follicles especially at high dose. This study provides preliminary evidence that paracetamol may lower gonadotropin and estradiol levels. These result agreed with (13) they reported that basal hormone levels especially Liutinize hormone (LH) were lower for women who regularly used paracetamol.

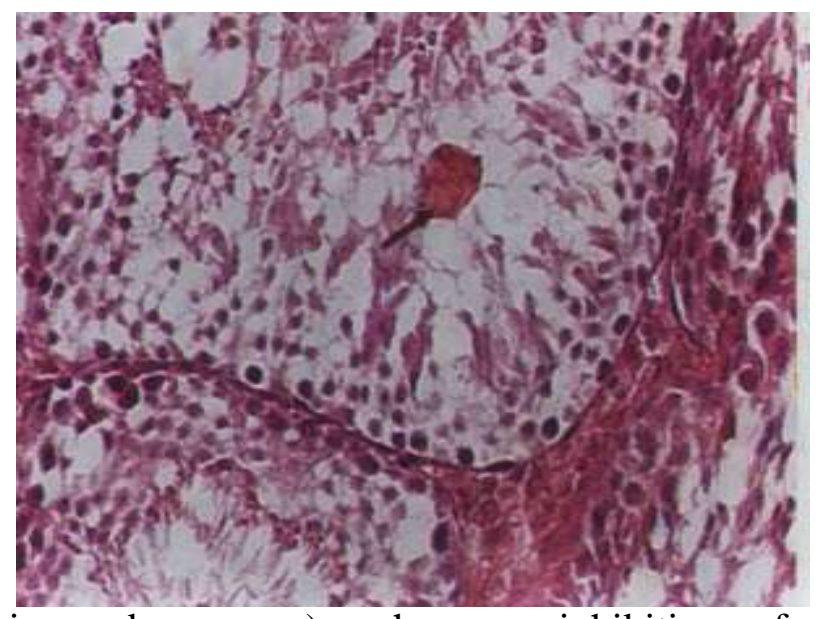

Figure(1): Testis (toxic dose group), show inhibition of spermatogenesis and presence of multinucleated giant cells (arrow)(X $100 \mathrm{H} \& \mathrm{E})$

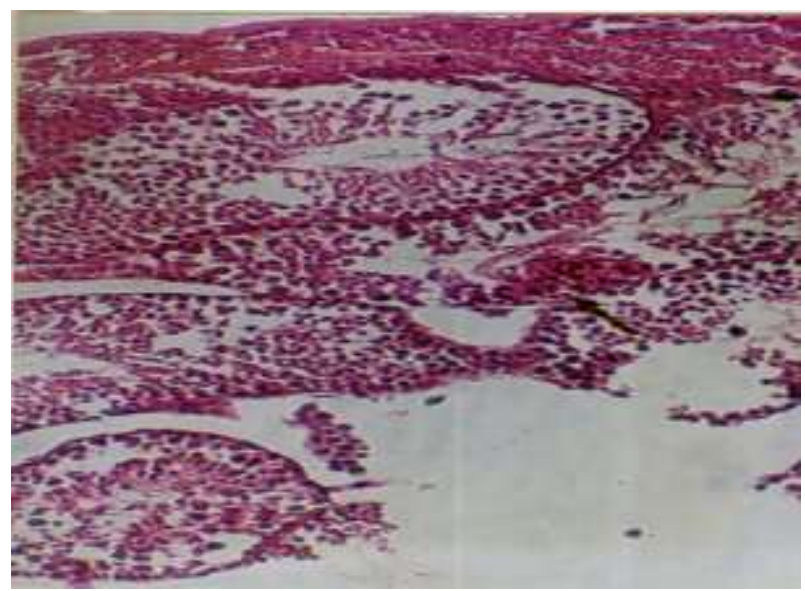

Figure(2):Testis (toxic dose group), show inhibition of spermatogenesis and presence of multinucleated giant cells(X $200 \mathrm{H} \& \mathrm{E})$. 


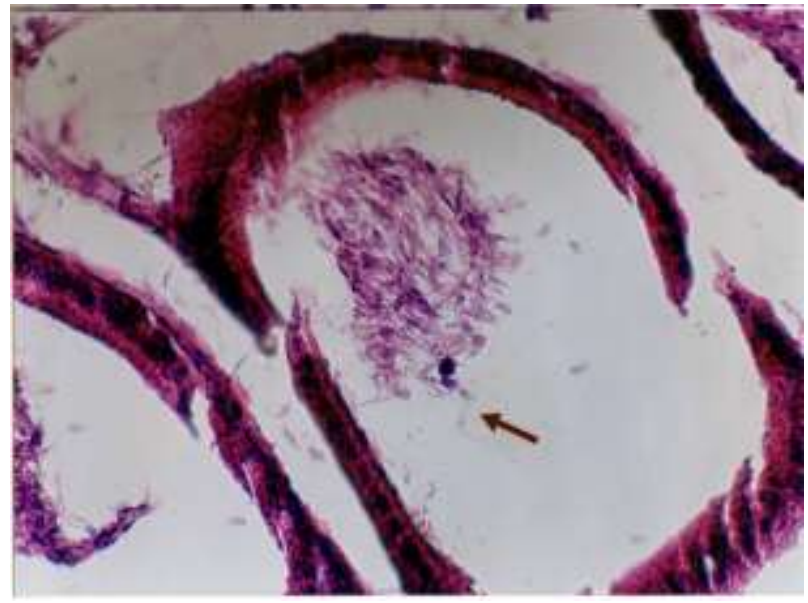

Figure(3): Epididymis( toxic dose.group) show empty of epididymis with no sperms in lumen(arrow). (X100 H\&E)

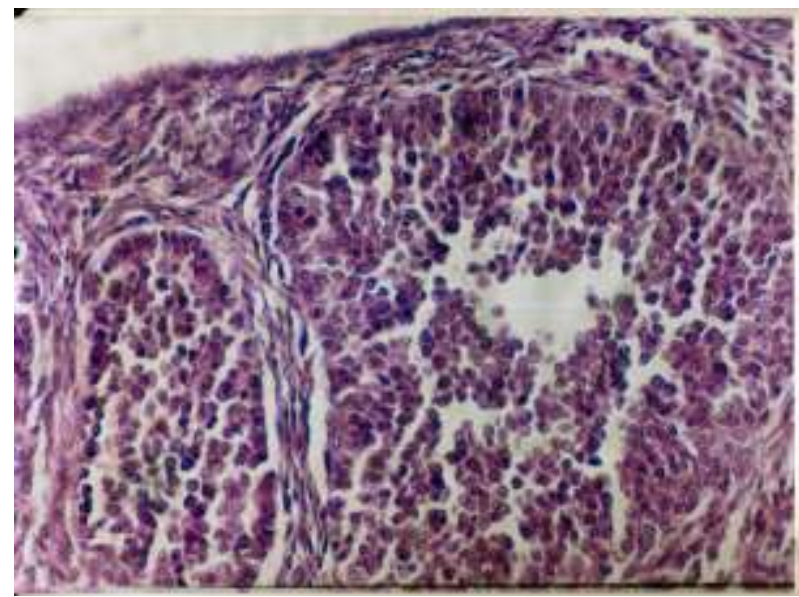

Figure(4): Ovary (toxic dose group) show no corpus leutium, only few follicles(X 100 $\mathrm{H} \& \mathrm{E})$

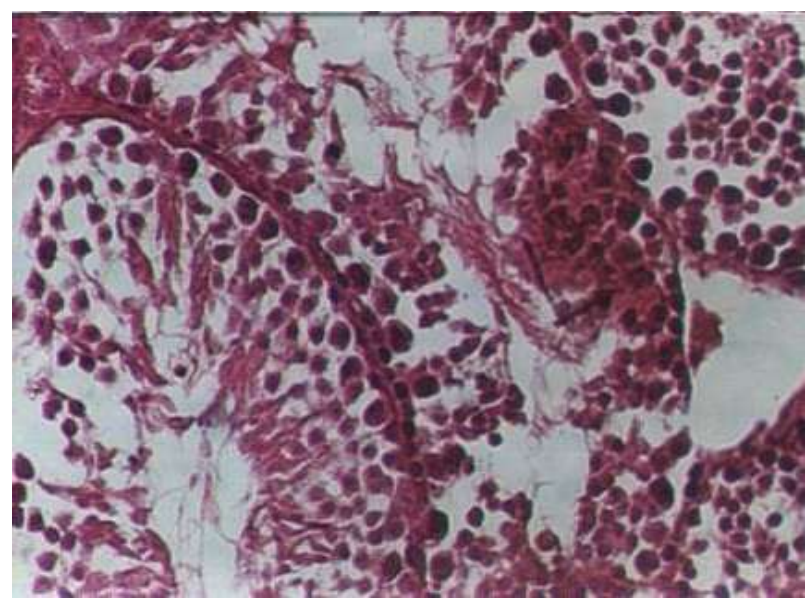

Figure(5): Testis (peracute dose group) show spermated degeneration with development of multinucleated spermatid giant cells(arrow) and occasional vacuolated of spermatogenia (double arrow) (X200 H\&E) 


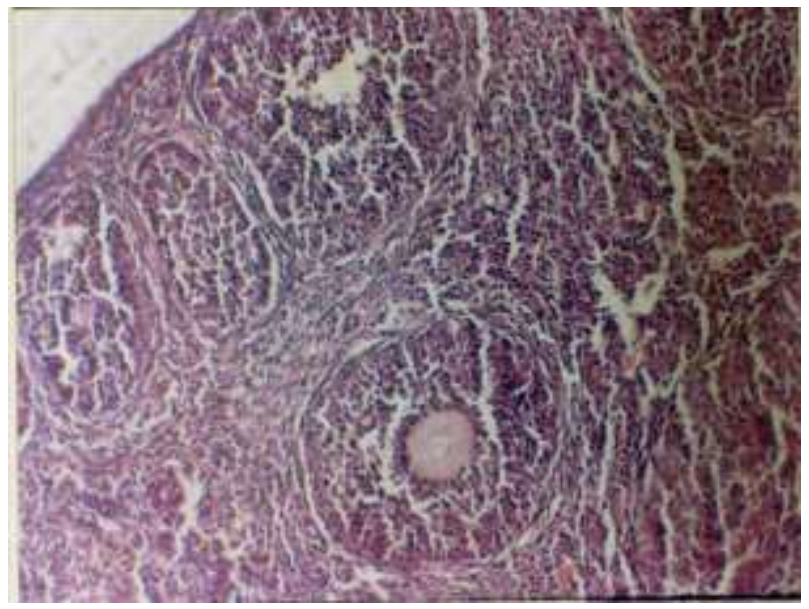

Figure(6): Ovary ( peracute dose group) show loss of corpus luteum ,few follicles and some grafian follicles were present (X50 H\&E)

\section{References}

1.Bennett P. N. and Brown M.J. (2003). Individual NSAID clinical pharmacology. $9^{\text {th }}$ ed. Chuchill Livingstone; 15: 287-288.

2.Botting R. (2004). Antipyretic therapy front Biosci; 1: 9956-9966.

3.Muldrew Kenneth L.; Laura P.J.; Leslie C.; Sandra S.M.; Howard P.H.; Jack A.H. and Philip R.M. (2003). Determination of acetaminophen-protein adducts in mouse liver and serum and human serum after hepatotoxic dose of acetaminophen using high-performance liquid chromatography with Electrochemical Detection. Drug metabolism and disposition; 30 (4): 446-451.

4.Ackermann Rernat Wilhelm. (2000). Paracetamol. Expert report on pharmaco-toxicological documentation; 1-33.

5.Swierkosz T.A.; Jordan L.; McBride, M.C. Gough K.; Devlin J. and Bolting R.M. (2002). Action of paracetamol on cyclo oxygenases in tissue and cell homogenates of mouse and rabbit. Med. Sci. monit.; 8 (12): 496-503.

6.Abrason S.R. and Weissmann G. (1989). The mechanism of action of non steroidal anti-inflammatory drugs. Arthritis Rheum; 52:1-9.

7.Juliette L.; Hasan Mukhtar; David R. Bickers; Levy Kopel orich and mohammad Athar. (2003). Cyclo oxygenases in the skin: pharmacological and toxicological implications. Toxicological and Applied pharmacology; 192 (3): 294-306.

8.Boutaud O.; Aron off D.M.; Richardson J.H.; Marnett L.T. and Oates J.A. (2002). Determinant of the inhibitor of prostaglandin $\mathrm{H} \mathrm{(2)}$ syntheses proc Natl Acad Sci U.S.A; 99 (10): 7130-7135.

9.Luna L.C. (1968). Manual of Histologic staining methods the armed forces. Institute of pathology. $3^{\text {rd }}$ ed., McGraw-Hillbook Company, New York, Toronto, London, Sydney; 12-31.

10. Camu Frederic M.D. (2002). Pharmacology of systemic analgesics Best Practice and research clinical anaesthesiology; 16 (4): 475-488. 11.Benson G.D.; Koff R.S. and Tolman K.G. (2005). The therapeutic use of acetaminophen in patients with liver disease. Amj. ther. (2): 133141.

11. Winger Richard; Jan K. Hongslo; Donald P. Evenson; Paula De Angelis; Per E. Schwarze and Jorn A. holme. (1995). Effect of Acetaminophen hydroxyurea on spermatogenesis and sperm chromatin structure in laboratory 
mice reproductive toxicology; 9 (1): 21-33.

12. Cramer D.W.; Liberman R.F.; Hornstein M.D.; Mcshane P.; powers D.; Li E. and Barbieri R.
(1998). Basal hormone level in women who use acetaminophen for menstrual pain. Fertile steril; 70 (2): 371-373.

\section{دراسة التغيرات المرضية الناتجة من التأثير السمي للباراسيتامول على الجهاز

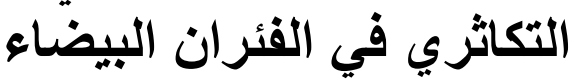

$$
\text { الخلاصة الطب البيطري, جامعة البصرة }
$$

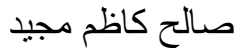$$
\text { اطباف غانم رهيف }
$$$$
\text { كلية الطب البيطري, جامعة القادسية }
$$

أجريت التجربة على 40 فأرة (20 ذكر و 20 أنثى) قسمت الى أربعة مجاميع كل مجموعة تحوي 10 فئران (5

المجمو عة الأولى(مجمو عة النمة السبطرة) استلمت ماء.

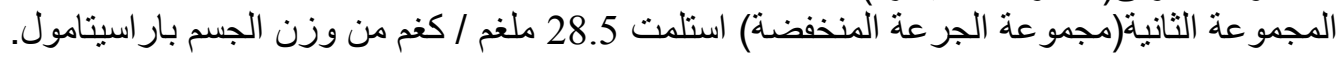

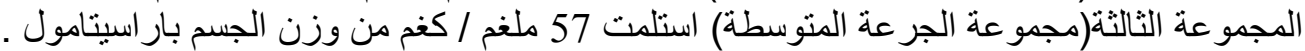

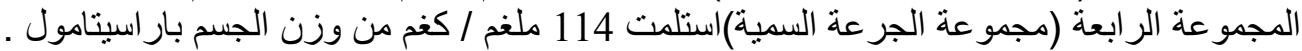

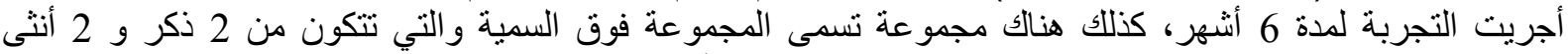

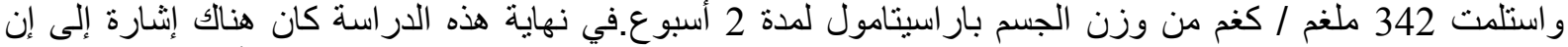
الجر عة السمية وفوق السمية سبيت تغير ات مرضية عيانية ومجهريه على الجهاز التكاثري الذكري والئ الأنثوي في الفئران. 